\title{
Characterization of Botryosphaeria dothidea Isolates Collected from Pistachio and Other Plant Hosts in California
}

\author{
Zhonghua Ma and Themis J. Michailides
}

Department of Plant Pathology, University of California Davis, Kearney Agricultural Center, 9240 South Riverbend Ave., Parlier 93648. Accepted for publication 28 January 2002.

\begin{abstract}
Ma, Z., and Michailides, T. J. 2002. Characterization of Botryosphaeria dothidea isolates collected from pistachio and other plant hosts in California. Phytopathology 92:519-526.

Eighty-six isolates of Botryosphaeria dothidea, the causal agent of Botryosphaeria panicle and shoot blight of pistachio, were collected from pistachio and other plant hosts in California. The isolates were characterized by microsatellite-primed polymerase chain reaction (MP-PCR), sequences of the nuclear ribosomal DNA internal transcribed spacer region (ITS1, 5.8S gene, and ITS2), morphological and cultural characters, osmotic and fungicide sensitivity, and pathogenicity on pistachio. Three groups of these isolates were identified based upon analysis of MP-PCR data and ITS sequences. Group I contained 43 pycnidiospore-derived isolates collected from pistachio and other hosts. Group II consisted of 20 ascosporic isolates obtained from a single sequoia plant. Group III consisted of 20 ascosporic isolates from three shoots on a single blackberry

plant, two pycnidiospore-derived isolates from incense cedar, and one from pistachio. Group I predominated over the other two groups in California pistachio orchards. B. dothidea isolates of group III grew faster on acidified potato dextrose agar (APDA) than the isolates of groups I and II. Isolates of group III produced pycnidia on both APDA and autoclaved pistachio shoots, but the isolates of the other two groups produced pycnidia on only autoclaved pistachio shoots. Additionally, significant differences in osmotic and fungicide sensitivities were observed among these three groups. Results from lathhouse inoculations demonstrated that the representative isolates for each of the three groups were all capable of infecting pistachio and producing characteristic disease symptoms of Botryosphaeria blight. The virulence of group II isolates on pistachio was, however, significantly lower than that of group I isolates.

Additional keywords: Fusicoccum sp., Pistacia vera, Rubus ursinus, Sequoiadendron giganteum.
\end{abstract}

Botryosphaeria panicle and shoot blight of pistachio, caused by Botryosphaeria dothidea (Moug.:Fr.) Ces. \& De Not., has become a destructive disease of pistachio (Pistacia vera) in California since the late 1980s. B. dothidea overwinters as pycnidia on infected pistachio twigs, rachises, buds, petioles, and in cankers that remain on trees and can provide pycnidiospore inoculum for up to 6 years (14). Kerman is the only commercial pistachio cultivar currently cultivated in California and it is susceptible to $B$. dothidea. Previously, there has been no effective control for Botryosphaeria blight. However, recently there has been success in controlling the disease with multiple sprays of strobilurin and sterol demethylation inhibitor fungicides (16). Because of the destructive nature of this disease, Botryosphaeria panicle and shoot blight has become a major threat to the California pistachio industry.

B. dothidea was first reported in California in 1966 on almond, causing bandlike cankers on the trunk or scaffolds of vigorous young trees (6). In 1984, this fungus was isolated for the first time from blighted shoots and panicles of pistachio in Durham, CA (23). In 1986, B. dothidea isolates were recovered from shoots of French prune, maple, sycamore maple, and pecan (13), along with giant sequoia and coastal redwood (30). From 1986 to 2000, B. dothidea was recovered from more than 35 different plant species in California (13). In previous studies, all pycnidiospore-derived isolates of $B$. dothidea collected from other hosts were capable of infecting pistachio, producing characteristic symptoms of Botryosphaeria blight $(9,13)$. This led to the speculation that other hosts

Corresponding author: T. J. Michailides; E-mail address: themis@uckac.edu

Publication no. P-2002-0319-01R

(c) 2002 The American Phytopathological Society may serve as potential inoculum sources for infection of commercial pistachio in California. However, no comparisons were conducted in the virulence of these isolates in these previous studies.

The teleomorphic stage of $B$. dothidea has never been found on pistachio. Various tests conducted in vitro and in vivo to produce the perfect stage of B. dothidea on pistachio had no success (T. J. Michailides, unpublished data). Although $B$. dothidea has been recovered from more than 35 different plant species in California, pseudothecia (ascocarps) were only occasionally found on blackberry, sequoia, olive, and avocado $(13,30)$. Thus, at present it is assumed that $B$. dothidea reproduces primarily asexually by means of pycnidiospores on California pistachio. Pycnidiospores of $B$. dothidea are not airborne (12) but dispersed by splashing rain or sprinkler irrigation water, insects, and birds (12,17). Ascospores producing on other hosts become airborne and may be important for the long-distance dispersal of the pathogen (13).

Identification and differentiation of Botryosphaeria spp. is difficult because the teleomorph is rarely encountered in nature and, when encountered, exhibits little variation among species (8). Thus, the taxonomy of the group is based primarily on characteristics of the anamorph. However, anamorphic characters may show extensive plasticity within some Botryosphaeria spp. $(4,20)$. Thus, neither characters of teleomorph nor anamorph are reliable for definitive identification of some Botryosphaeria spp. with hyaline-pycnidiospores. Recently, nuclear ribosomal DNA internal transcribed spacers (ITS1 and ITS2) have been used successfully to analyze intraspecific and interspecific relationships in various fungi (1). In some cases, ITS sequences have allowed species identification where morphological characters have not been useful $(22,29)$.

Identification of the pistachio panicle and shoot blight pathogen as the anamorph of $B$. dothidea (11) was based on comparisons of morphological and cultural characteristics of several isolates from 
pistachio with those of a fungus identified as $B$. dothidea that causes bandlike canker of almonds in California (6) and with those of isolates of $B$. dothidea from peach in Georgia (2). Recently, Smith et al. (25) compared isolates of this pathogen from California pistachio with the isolates of $B$. dothidea and B. ribis and found that the pistachio isolates separated as a taxonomic clade between $B$. dothidea and $B$. ribis isolates. At the time when Michailides (11) identified the species causing Botryosphaeria panicle and shoot blight of pistachio, B. dothidea and B. ribis were considered synonymous (3). Currently, considerable controversy still exists surrounding the taxonomic status of $B$. dothidea and $B$. ribis. Some authors regard the two species as synonyms, while others treat them as separate taxa (27).

Because anamorphic characters may show extensive plasticity among Botryosphaeria spp., one of the objectives of this study was to further identify the pistachio blight pathogen by comparing the ITS sequences of pistachio isolates with those of $B$. dothidea isolates studied previously. Our second objective was to compare morphological and molecular characters of pycnidiospore-derived isolates of $B$. dothidea collected from pistachio with pycnidiospore or ascosporic isolates from other hosts in California.

TABLE 1. A list of Botryosphaeria dothidea isolates collected from pistachio and other hosts in California used in this study

\begin{tabular}{|c|c|c|c|}
\hline Isolate $^{z}$ & Host & Location (city, county) & Isolation date \\
\hline CE347 & Cedar & Clovis, Fresno & 07/05/99 \\
\hline CE348 & Cedar & McCall, Fresno & 07/13/99 \\
\hline CE403 & Cedar & Reedley, Fresno & 07/26/99 \\
\hline CE412 & Cedar & Fresno & 07/26/99 \\
\hline EU353 & Eucalyptus & Clovis, Fresno & 06/16/99 \\
\hline EU356 & Eucalyptus & Clovis, Fresno & $06 / 26 / 99$ \\
\hline EU402 & Eucalyptus & Fresno & 07/22/99 \\
\hline JA358 & Jasmine & McCall, Fresno & 07/26/99 \\
\hline JU38-40 & Juniper & Clovis, Fresno & $06 / 15 / 99$ \\
\hline JU394 & Juniper & Reedley, Fresno & 07/03/99 \\
\hline JU395 & Juniper & Reedley, Fresno & 07/03/99 \\
\hline PE361 & Pear & Stockton, San Joaquin & $06 / 25 / 99$ \\
\hline PI497-499 & Pistachio & Parlier, Fresno & 05/03/00 \\
\hline PI565-567 & Pistachio & Tulare & $05 / 12 / 00$ \\
\hline PI568 & Pistachio & Tulare & 05/17/00 \\
\hline PI579 & Pistachio & Fresno & $05 / 24 / 99$ \\
\hline PI624 & Pistachio & Reedley, Fresno & 03/06/00 \\
\hline PI719 & Pistachio & Fresno & $05 / 03 / 00$ \\
\hline PI764 & Pistachio & Tulare & $05 / 24 / 00$ \\
\hline PI766 & Pistachio & Tulare & $05 / 24 / 00$ \\
\hline RA363 & Raymond ash & Clovis, Fresno & 07/05/99 \\
\hline RE276 & Redwood & Reedley, Fresno & $10 / 21 / 97$ \\
\hline RE279 & Redwood & Reedley, Fresno & $10 / 21 / 97$ \\
\hline RE282 & Redwood & Madera & $10 / 21 / 97$ \\
\hline RE288 & Redwood & Madera & $10 / 21 / 97$ \\
\hline RE289 & Redwood & Hanford, Kings & $01 / 16 / 98$ \\
\hline RE290-292 & Redwood & Hanford, Kings & $01 / 16 / 98$ \\
\hline RE365 & Redwood & Kearney, Fresno & 07/14/99 \\
\hline WA370 & Walnut & Manning, Fresno & 07/08/99 \\
\hline WA371 & Walnut & Los Banos, Madera & 07/11/99 \\
\hline WA372 & Walnut & McCall, Fresno & 07/12/99 \\
\hline WA373 & Walnut & McCall, Fresno & 07/12/99 \\
\hline WA389 & Walnut & San Joaquin & 04/23/99 \\
\hline WA408 & Walnut & Merced & 07/22/99 \\
\hline WA409 & Walnut & Merced & 07/24/99 \\
\hline PIL22 & Pistachio & Kaplan, Glenn & 09/12/99 \\
\hline CEL948 & Cedar & Butte & $11 / 16 / 00$ \\
\hline CEL950 & Cedar & Butte & $11 / 16 / 00$ \\
\hline SAS01-20 & Sequoia & Kearney, Fresno & 01/24/01 \\
\hline BAS21-24 & Blackberry & Hansen, Glenn & $04 / 04 / 00$ \\
\hline BAS26-30 & Blackberry & Hansen, Glenn & $04 / 04 / 00$ \\
\hline BAS32-37 & Blackberry & Hansen, Glenn & $04 / 04 / 00$ \\
\hline BAS39-43 & Blackberry & Hansen, Glenn & $04 / 04 / 00$ \\
\hline
\end{tabular}

${ }^{\mathrm{z}}$ Twenty single-ascosporic isolates designated as SAS were collected from one sequoia plant, 20 single-ascosporic isolates designated as BAS were recovered from three branches on a single blackberry plant, and others were single pycnidiospore-derived isolates.

\section{MATERIALS AND METHODS}

Fungal isolate collections. During 1997 to 2000, blighted or dead shoots from pistachio and various other plant hosts of $B$. dothidea were collected throughout California. To obtain single spore isolates, infected plants were examined for $B$. dothidea infections and for characteristic pycnidia or pseudothecia of the pathogen. Isolation and morphological confirmation of $B$. dothidea single pycnidiospore or ascosporic isolates was performed according to previously established protocol $(9,11)$. In this study, ascosporic isolates were collected from a single sequoia and a blackberry plant because the teleomorphic stage of $B$. dothidea is rarely encountered in nature and it is not easily found in California. The isolates used in this study are listed in Table 1.

Microsatellite-primed polymerase chain reaction amplifications and data analysis. Genomic DNA extraction for $B$. dothidea isolates was performed according to a previously established protocol (9), except that $2 \times$ CTAB extraction buffer ( $2 \%$ hexadecyltreimethylammonium bromide [CTAB], $700 \mathrm{mM} \mathrm{NaCl}$, $100 \mathrm{mM}$ Tris- $\mathrm{HCl}, \mathrm{pH}$ 8.0, $10 \mathrm{mM}$ EDTA, and $1 \% \beta$-mercaptoethanol) was used in this study. For microsatellite-primed polymerase chain reaction (MP-PCR), a total of 19 microsatellite primers were screened for their utility in producing PCR products. To optimize conditions, a range of template (10 to $100 \mathrm{ng}$ ) and $\mathrm{MgCl}_{2}$ concentrations (1 to $5 \mathrm{mM}$ ), as well as a series of different annealing temperatures, were evaluated. After PCR conditions were optimized, reactions were performed by a thermal cycler (Model 480; Perkin-Elmer Corp., Norwalk, CT) in 50- $\mu$ l volume containing $50 \mathrm{ng}$ of fungal genomic template, $1.0 \mu \mathrm{M}$ each microsatellite primer, $0.2 \mathrm{mM}$ each dNTP, $2.0 \mathrm{mM} \mathrm{MgCl} 2,1 \times$ Promega Taq polymerase buffer $(10 \mathrm{mM}$ Tris- $\mathrm{HCl}, \mathrm{pH} 9.0,50 \mathrm{mM} \mathrm{KCl}$, and $0.1 \%$ Triton X-100), and 1.5 units of Promega Taq polymerase. The PCR was performed using the following parameters: an initial preheat for $3 \mathrm{~min}$ at $95^{\circ} \mathrm{C}$, followed by 40 cycles of denaturation at $94^{\circ} \mathrm{C}$ for $1 \mathrm{~min}$, annealing at $50^{\circ} \mathrm{C}$ for $1 \mathrm{~min}$, extension at $72^{\circ} \mathrm{C}$ for $1.5 \mathrm{~min}$, and terminated with a final extension at $72^{\circ} \mathrm{C}$ for $10 \mathrm{~min}$. PCR was performed twice for each isolate. The PCR products were separated on $1.5 \%$ agarose gels in Tris-acetate (TAE) buffer and photographed after staining with ethidium bromide.

For analysis of MP-PCR data set, each isolate was scored for the presence or absence of each amplicon using Kodak Digital Science ID Image Analysis Software (Eastman Kodak Co., Rochester, NY). Genetic similarities $(S)$ were calculated using the coefficient of similarity given by Nei and $\mathrm{Li}$ (19) as $S=2 N_{a b} /$ $\left(N_{a}+N_{b}\right)$, where $N_{a b}$ is the number of amplicons shared by two isolates, and $N_{a}$ and $N_{b}$ are the number of amplicons found in isolates $a$ and $b$, respectively. A phenogram was constructed by the program SIMQUAL and SAHN of the software package NTSYSpc 2.1 (Department of Ecology and Evolution, State University of New York) using the unweighted pair-group method with arithmetic average (UPGMA). To determine the support of each clade, bootstrap analysis was performed with 1,000 replicates by a computer program phylogenetic analysis using parsimony (PAUP 4.0beta Win, Sinauer Associates, Sunderland, MA). Estimates of genetic diversity within group I were performed with Nei's haplotypic diversity index $(H s)$ (18) using the computer software POPGENE (version 1.32, University of Alberta, Edmonton, Canada).

DNA sequences of ITS region. Three to five representative isolates from each group (Table 2) that were differentiated by MPPCR analysis were selected for ITS sequence analysis. The ITS sequences of recently published $B$. dothidea isolates were obtained from GenBank (Table 2).

The ITS region of the $B$. dothidea isolate was amplified using fungal universal primers ITS1 and ITS4 (28). The PCR was performed in $100 \mu \mathrm{l}$ containing $10 \mathrm{ng}$ of fungal genomic template, $1.0 \mu \mathrm{M}$ each primer, $0.2 \mathrm{mM}$ each dNTP, $2.0 \mathrm{mM} \mathrm{MgCl}_{2}, 1 \times$ 
Promega Taq polymerase buffer, and 1.5 units of Promega Taq polymerase. The PCR was performed with the following parameters: an initial preheat for $3 \mathrm{~min}$ at $95^{\circ} \mathrm{C}$, followed by 35 cycles of denaturation at $94^{\circ} \mathrm{C}$ for $1 \mathrm{~min}$, annealing at $58^{\circ} \mathrm{C}$ for $1 \mathrm{~min}$, extension at $72^{\circ} \mathrm{C}$ for $1.5 \mathrm{~min}$, and terminated with a final extension at $72^{\circ} \mathrm{C}$ for $10 \mathrm{~min}$. PCR products were verified on $1.5 \%$ agarose gels in TAE buffer. The products were purified with a PCR purification kit (QIAquick; Qiagen Inc., Valencia, CA) and sequenced by DBS Sequencing (Division of Biological Sciences, University of California, Davis).

Complete sequences for the ITS region (ITS1, 5.8S gene, and ITS2) were aligned using the computer program Clustal W 1.81 (European Bioinformatics Institute, Cambridge, UK). Phylogenetic relationships among the isolates of $B$. dothidea were determined from the aligned sequences using PAUP. Nucleotide substitutions were treated as unordered, unweighted characters. Maximum parsimony trees were inferred using the heuristic search option with 1,000 random addition replicates with the tree bisection reconnection algorithm. Support for the clades was assessed by 1,000 bootstrap replicates. The B. obtusa isolate 93.56 was used as an outgroup isolate.

Morphological and cultural characterization. Morphological and cultural characters were determined by mycelial growth rate, pycnidia production on acidified $(2.5 \mathrm{ml}$ of a $25 \%$ [ $\mathrm{vol} / \mathrm{vol}]$ solution of lactic acid per liter of medium) potato dextrose agar (APDA) (Microtech Scientific, Orange, CA) and on autoclaved pistachio shoots. To measure the mycelial growth rate, a 5-mm mycelial plug of each isolate was taken from the edge of a 3-dayold colony and placed on the center of an APDA dish. Two replicates for each isolate were used. Radial growth of each isolate was measured after 2 days of incubation at $28^{\circ} \mathrm{C}$ in the dark. The experiment was performed twice, and data of the two experiments were combined to calculate average colony diameter for each isolate since no significant difference $(P>0.05)$ between two experiments was found. Analysis of variance (ANOVA) in mycelial growth rate among the three groups was conducted using the ANOVA procedure of SAS (version 8.0; SAS Institute, Cary, NC).

Pycnidial production on APDA was examined for each isolate after incubation at $28^{\circ} \mathrm{C}$ for 10 days under the continuous 3,900 lumens of cool white fluorescent lights (Philips Lighting Company, Somerset, NJ). To produce pycnidia of B. dothidea in vitro, a mycelial plug for each isolate was transferred onto an autoclaved pistachio shoot that was placed on the surface of agar in a petri dish supplemented with a $5 \mathrm{ml}$ of agar in the bottom. Four replicate petri dishes were used for each isolate. After 2 weeks of

TABLE 3. A list of primers that generated polymorphic banding patterns for the isolates of Botryosphaeria dothidea collected from pistachio and other hosts in California

\begin{tabular}{llc}
\hline Primer & Sequence 5' $\rightarrow 3^{\prime}$ & $\begin{array}{c}\text { Polymorphic } \\
\text { fragments }\end{array}$ \\
\hline$(\text { AAC })_{8}$ & AAC AAC AAC AAC AAC AAC AAC AAC & 13 \\
$(\mathrm{AAG})_{8}$ & AAG AAG AAG AAG AAG AAG AAG AAG & 12 \\
$(\mathrm{AG})_{8} \mathrm{C}$ & AGA GAG AGA GAG AGA GC & 12 \\
$(\mathrm{CTC})_{4} \mathrm{RC}$ & CTC CTC CTC CTC RC & 15 \\
T3B & AGG TCG CGG GTT CGA ATC C & 14 \\
M13 & GAG GGT GGC GGT TCT & 12 \\
Eric1 + Eric2 & ATC TAA GCT CCT GGG GAT TCA C & 10 \\
& AAG TAA GTG ACT GGG GTG AGC G & \\
\hline
\end{tabular}

TABLE 2. Isolates of Botryosphaeria dothidea and other outgroup isolates of Botryosphaeria spp. used in analysis of DNA sequences of internal transcribed spacer region

\begin{tabular}{|c|c|c|c|c|c|}
\hline Isolate no. & Species & Location & Collector & GenBank Accession No. & Reference \\
\hline CE347 & B. dothidea & California & T. J. Michailides & AF452702 & Present study \\
\hline PI497 & B. dothidea & California & T. J. Michailides & AF452704 & Present study \\
\hline PI565 & B. dothidea & California & T. J. Michailides & AF452705 & Present study \\
\hline RE282 & B. dothidea & California & T. J. Michailides & AF452701 & Present study \\
\hline WA372 & B. dothidea & California & T. J. Michailides & AF452703 & Present study \\
\hline BAS22 & B. dothidea & California & T. J. Michailides & AF464944 & Present study \\
\hline BAS23 & B. dothidea & California & T. J. Michailides & AF464945 & Present study \\
\hline BAS39 & B. dothidea & California & T. J. Michailides & AF464946 & Present study \\
\hline CEL948 & B. dothidea & California & T. J. Michailides & AF464947 & Present study \\
\hline PIL22 & B. dothidea & California & T. J. Michailides & AF464948 & Present study \\
\hline SAS1 & B. dothidea & California & T. J. Michailides & AF464949 & Present study \\
\hline SAS7 & B. dothidea & California & T. J. Michailides & AF464950 & Present study \\
\hline SAS17 & B. dothidea & California & T. J. Michailides & AF464951 & Present study \\
\hline 93.03 & B. dothidea & District of Columbia & K. A. Jacobs & AF027742 & 8 \\
\hline 93.12 & B. dothidea & District of Columbia & K. A. Jacobs & AF027746 & 8 \\
\hline 93.23 & B. dothidea & District of Columbia & K. A. Jacobs & AF027751 & 8 \\
\hline 93.42 & B. dothidea & District of Columbia & K. A. Jacobs & AF027741 & 8 \\
\hline 94.23 & B. dothidea & Georgia & P. L. Pusey & AF027747 & 8 \\
\hline 94.26 & B. dothidea & Japan & P. L. Pusey & AF027749 & 8 \\
\hline 94.27 & B. dothidea & Georgia & P. L. Pusey & AF027748 & 8 \\
\hline 97.5 & B. dothidea & Wisconsin & P. McManus & AF241173 & 26 \\
\hline 97.23 & B. dothidea & South Carolina & K. Britton & AF241174 & 26 \\
\hline 97.94 & B. dothidea & New Zealand & G. J. Samuels & AF241175 & 26 \\
\hline BOT7 & B. dothidea & Mpumalanga, R. S. A. & H. Smith & AF283678 & 27 \\
\hline BOT21 & B. dothidea & Mpumalanga, R. S. A. & H. Smith & AF283681 & 27 \\
\hline BOT25 & B. dothidea & Swaziland & H. Smith & AF283679 & 27 \\
\hline BOT681 & B. dothidea & KwaZulu-Natal, R. S. A. & H. Smith & AF283676 & 27 \\
\hline BOT682 & B. dothidea & KwaZulu-Natal, R. S. A. & H. Smith & AF283680 & 27 \\
\hline ВОТ683 & B. dothidea & KwaZulu-Natal, R. S. A. & H. Smith & AF283677 & 27 \\
\hline ВОT6.1 & B. dothidea-complex & South Africa & S. Denman & AF195774 & 5 \\
\hline BOT8.4 & B. dothidea-complex & South Africa & S. Denman & AF196294 & 5 \\
\hline ВОT9.3 & B. dothidea-complex & South Africa & S. Denman & AF196295 & 5 \\
\hline BOT10.2 & B. dothidea-complex & South Africa & S. Denman & AF196296 & 5 \\
\hline BOT11.1 & B. dothidea-complex & South Africa & S. Denman & AF196297 & 5 \\
\hline BOT12.3 & B. dothidea-complex & South Africa & S. Denman & AF196298 & 5 \\
\hline 93.56 & B. obtusa & New York & G. J. Samuels & AF027759 & 8 \\
\hline BOT2.2 & B. proteae & South Africa & S. Denman & AF196299 & 5 \\
\hline BOT3.3 & B. proteae & South Africa & S. Denman & AF196300 & 5 \\
\hline
\end{tabular}


incubation at room temperature $\left(25 \pm 2^{\circ} \mathrm{C}\right)$ under the continuous 3,900 lumens of cool white fluorescent lights, each isolate was examined for the presence (+) or absence (-) of pycnidia on autoclaved pistachio shoots.

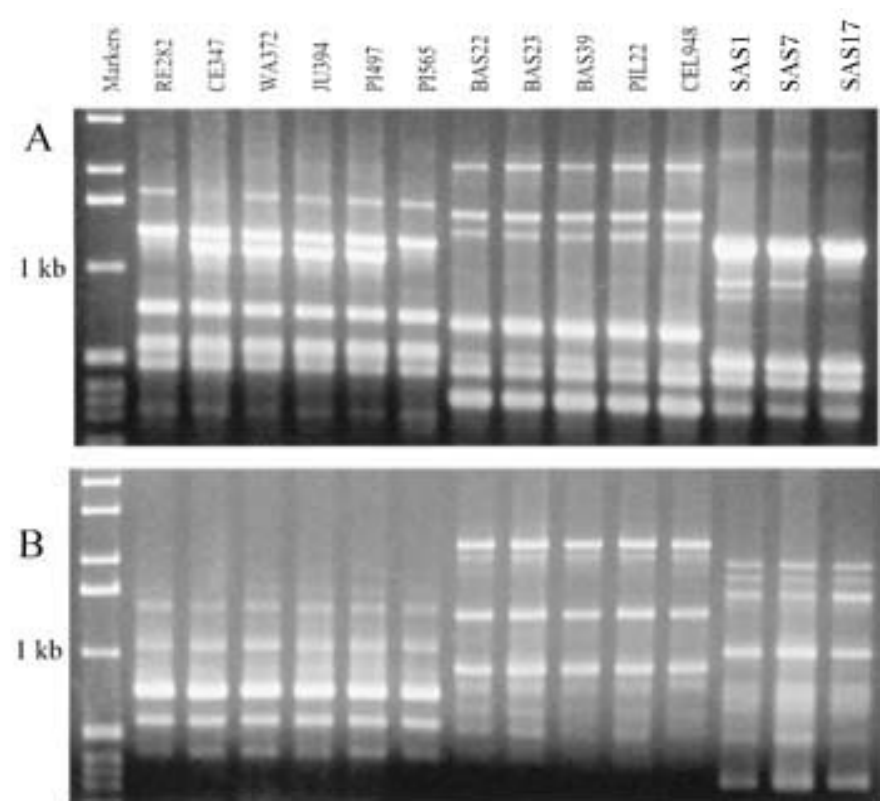

Fig. 1. Electrophoretic separation of polymerase chain reaction amplicons of Botryosphaeria dothidea isolates obtained from primers $\mathbf{A}, \mathrm{T} 3 \mathrm{~B}$ and $\mathbf{B},(\mathrm{AAG})_{8}$.
Measurement of osmotic sensitivity. APDA was used as a basic medium. Various amounts of $\mathrm{KCl}(24)$ were added to the media to create different water potential levels ranging from -0.3 to $-14 \mathrm{MPa}$. For each isolate, a 5-mm mycelial plug was cut from the edge of a 3-day-old colony and transferred to an APDA dish, each containing $20 \mathrm{ml}$ of medium amended with $\mathrm{KCl}$. Two replicates per $\mathrm{KCl}$ concentration were used for each isolate. All dishes were sealed with Parafilm. After incubation at $28^{\circ} \mathrm{C}$ in the dark for 2 days, colony diameters for each isolate were measured in two perpendicular directions. The experiment was performed twice. Data of two experiments were combined to calculate average colony diameter for each isolate at each $\mathrm{KCl}$ concentration since there was no significant difference $(P>0.05)$ between the two experiments. ANOVA in osmotic sensitivity among the three groups was conducted using the ANOVA procedure of SAS.

Detection of fungicide sensitivity. Technical tebuconazole (a.i. 97.5\%; Bayer AG Inc., Bayerwerk, Germany) was dissolved in ethanol, adjusted to a concentration of stock solution at $10 \mu \mathrm{g} / \mu \mathrm{l}$, and added to APDA to produce six concentrations: 0, 0.0625, $0.125,0.25,0.5$, and $1.0 \mu \mathrm{g}$ of tebuconazole per $\mathrm{ml}$ of medium. A 5-mm mycelial plug was cut from the edge of a 3-day-old colony of each isolate and placed on the center of an APDA dish amended with each concentration of the fungicide. For each isolate, two replicates per concentration were used. Radial growth of each isolate was measured in millimeters, with the original mycelial plug diameter $(5 \mathrm{~mm})$ subtracted from this measurement, after 2 days of incubation at $28^{\circ} \mathrm{C}$ in the dark. For each isolate, a linear regression of the percent inhibition related to the control of mycelial

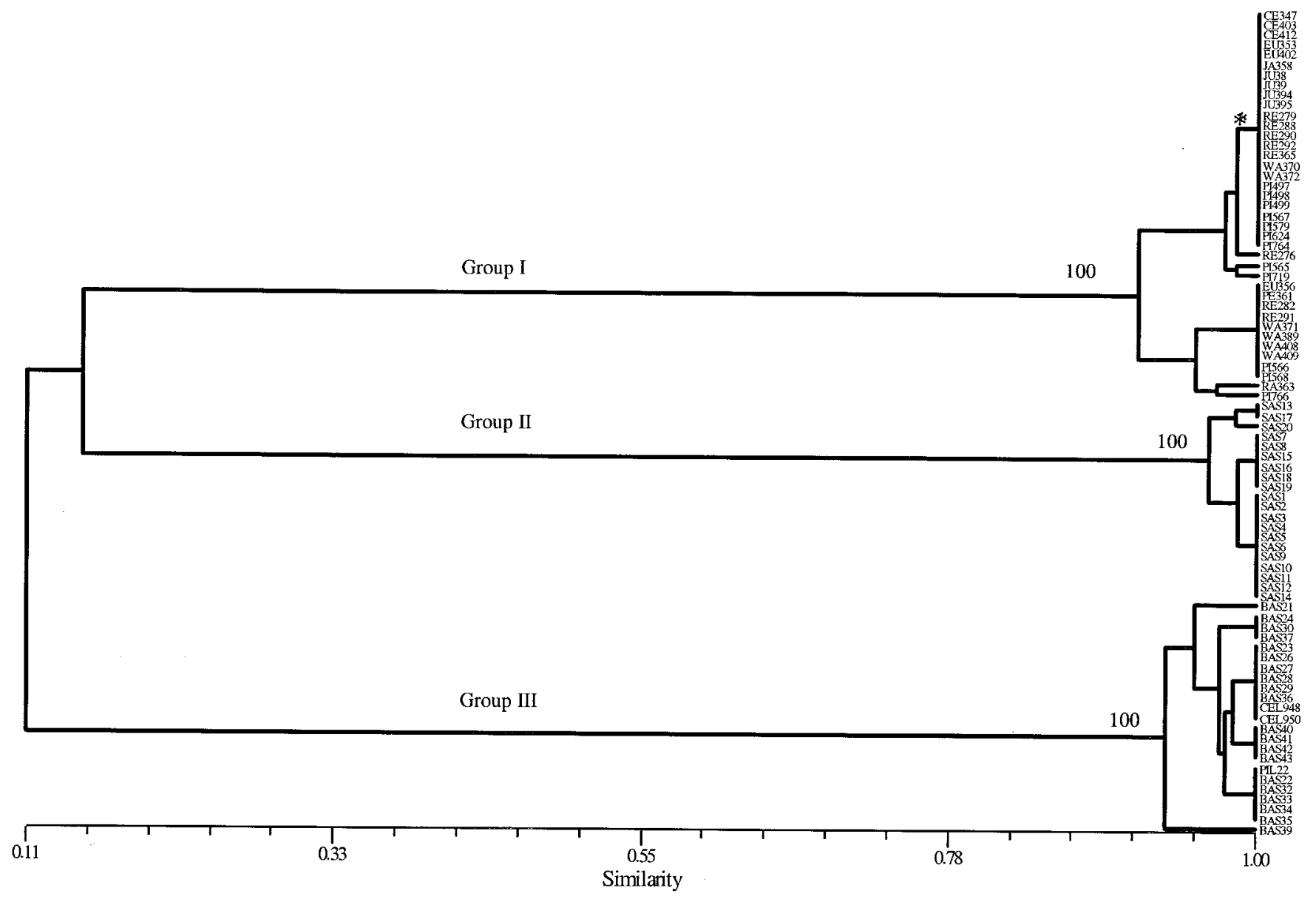

Fig. 2. Phenogram generated by the unweighted pair-group method with arithmetic average cluster analysis of microsatellite-primed polymerase chain reaction data sets from the Botryosphaeria dothidea isolates collected from pistachio and other hosts in California. Values on the branches of the clusters represent the results of bootstrap analysis (the percentage of times the group occurred during 1,000 replications). Asterisk denotes that the isolates CE348, JU40, RE289, and WA373 clustered in this branch are not shown in the figure because each branch could not hold more than 24 isolates. 
growth versus the $\log _{10}$ transformation for each of the five concentrations of tebuconazole was obtained. The $50 \%$ effective concentration $\left(\mathrm{EC}_{50}\right)$, which is the fungicide concentration that inhibited $50 \%$ mycelial growth, was obtained from the regression for each isolate. ANOVA in fungicide sensitivity among the three groups was conducted using the ANOVA procedure of SAS.

Pathogenicity tests. The same isolates from California (Table 2) used in ITS analysis were used in pathogenicity tests. The pistachio cv. Kerman was selected for lathhouse inoculations.
Artificial inoculation was performed with both mycelial plugs and spore suspensions. For the mycelial plug inoculation, each shoot on a potted 2-year-old pistachio tree was inoculated with each isolate by inserting a 5-mm mycelial plug in a wound created with a 5-mm-diameter cork borer and wrapped with Parafilm. Six shoots were used for each isolate. The blighted shoots were recorded for each isolate 10 and 20 days after inoculation, respectively. For spray of the spore suspension, three replicate shoots were sprayed with each spore suspension at a concentration of

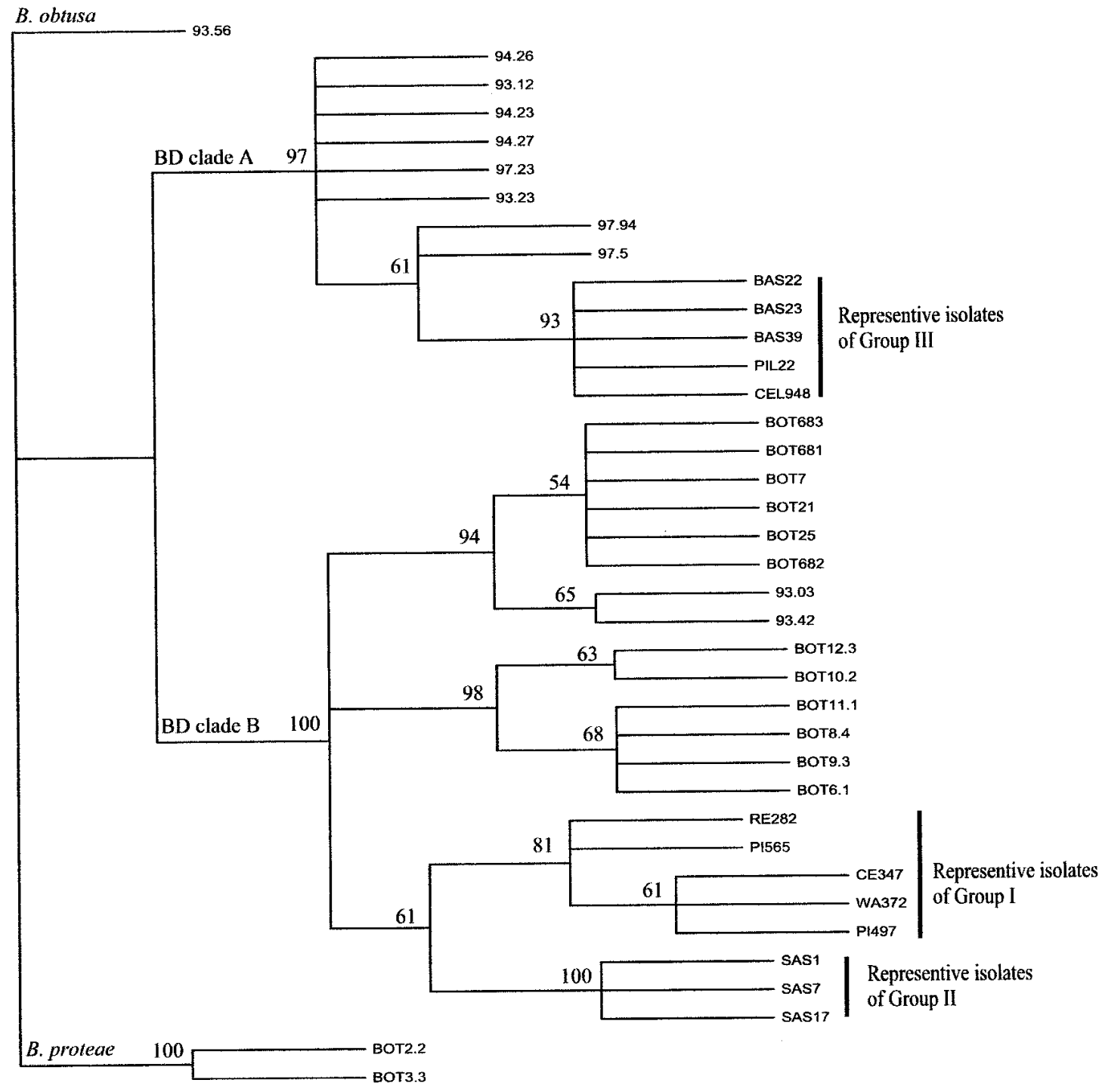

Fig. 3. Phylogenetic relations among the isolates of Botryosphaeria dothidea based on maximum parsimony analysis of internal transcribed spacer 1 and 2 and 5.8S rDNA sequence data. Tree length $=230$, consistency index $=0.8217$, retention index $=0.9420$, and rescaled consistency index $=0.7741$. Numbers on branches are bootstrap frequencies from 1,000 replicates of a heuristic search. Bootstrap frequencies lower than 50\% are not shown.

TABLE 4. Growth rate on acidified potato dextrose agar (APDA), production of pycnidia on APDA and on autoclaved pistachio shoots, and sensitivity to tebuconazole of Botryosphaeria dothidea isolates collected from pistachio and other hosts in California

\begin{tabular}{|c|c|c|c|c|c|c|}
\hline \multirow{2}{*}{$\begin{array}{l}\text { Group of } \\
B \text {. dothidea isolates }\end{array}$} & \multicolumn{2}{|c|}{ Growth rate on APDA (cm/day) } & \multirow{2}{*}{$\begin{array}{c}\text { Production of } \\
\text { pycnidia on APDA }^{w}\end{array}$} & \multirow{2}{*}{$\begin{array}{l}\text { Production of pycnidia } \\
\text { on pistachio shoots }\end{array}$} & \multicolumn{2}{|c|}{ Sensitivity to tebuconazole $(\mu \mathrm{g} / \mathrm{ml})$} \\
\hline & Mean $^{v}$ & Range & & & Meany & Range \\
\hline Group I $(n=43)$ & $2.34 \mathrm{~b}^{\mathrm{z}}$ & $2.00-2.60$ & - & + & $0.0777 \mathrm{c}^{\mathrm{z}}$ & $0.024-0.112$ \\
\hline Group II $(n=20)$ & $1.71 \mathrm{c}$ & $1.45-2.05$ & - & + & $0.0976 \mathrm{~b}$ & $0.069-0.146$ \\
\hline Group III $(n=23)$ & $3.88 \mathrm{a}$ & $3.35-4.40$ & + & + & $0.1666 \mathrm{a}$ & $0.122-0.291$ \\
\hline
\end{tabular}

${ }^{v}$ Data presented in columns are the average growth rate of the isolates of each group.

${ }^{w}$ - denotes that the isolates did not produce pycnidia and pycnidiospores of $B$. dothidea on APDA, and + denotes that the isolates did.

$\mathrm{x}+$ denotes that the isolates produced characteristic pycnidia and pycnidiospores of $B$. dothidea on autoclaved pistachio shoots.

$\mathrm{y}$ The values in columns are the average of $50 \%$ effective concentration $\left(\mathrm{EC}_{50}\right)$ to tebuconazole of the isolates of each group.

${ }^{\mathrm{z}}$ Values in each column followed by the same letter are not significantly different according to LSD at $P=0.05$. 
20,000 spores per $\mathrm{ml}$ with a hand-held sprayer until a fine film of droplets was deposited uniformly on the leaves. To create favorable conditions for infection, each inoculated shoot was covered with a plastic bag for $12 \mathrm{~h}$. The disease incidence was recorded for each shoot 1 month after inoculation. The following system was used for severity assessment: $0=$ leaves without lesions, $1=$ lesion area less than one-fourth of the leaf area, $2=$ lesion area between one-fourth and one-half of the leaf area, 3 = lesion area between one-half and three-fourths of the leaf area, and $4=$ lesion area greater than three-fourths of the leaf area. The disease index (DI) for each shoot was calculated using the formula

$$
\mathrm{DI}=\left(\sum_{i=0}^{4} N_{i} \times i\right) / \sum_{i=0}^{4} N_{i}
$$

where $i$ is severity ( 0 to 4 ) and $N_{i}$ is the number of leaves with the severity of $i$. The experiment was performed twice, and ANOVA in DI among the three groups was conducted using the ANOVA procedure of SAS.

\section{RESULTS}

MP-PCR. Seven of nineteen tested primers (Table 3) consistently generated a total of 88 polymorphic amplicons for 86 isolates of $B$. dothidea. Examples of MP-PCR using primer T3B or $(\mathrm{AAG})_{8}$ are presented in Figure 1 . Three groups were clearly classified by UPGMA analysis of microsatellite data set (Fig. 2). Bootstrap analysis showed that all major branches were supported at the $100 \%$ level. Group I contained 43 of 46 pycnidiospore-derived isolates collected from pistachio and other hosts at different locations in different years. Group II consisted of 20 ascosporic isolates obtained from a sequoia tree. Group III had 20 ascosporic isolates from a blackberry plant, two pycnidiospore-derived isolates from incense cedar, and one pycnidiospore-derived isolate from pistachio. A very low level of genetic variation (haplotypic diversity $[H s]=0.02$ ) was observed among the pycnidiosporederived isolates of group I collected from different host plants in different years.

ITS sequence data. For each of 13 tested isolates from pistachio and other hosts in California, an approximate 540-bp PCR product was amplified by primers ITS1 and ITS4. The sequences of ITS region (including ITS1, 5.8S gene, and ITS2) of our isolates were aligned with those of $B$. dothidea isolates generated by Denman et al. (5), Jacobs and Rehner (8), Smith and Stanosz (26), and Smith et al. (27) using the computer software Clustal W 1.81. The alignment contained 424 constant characters and 87 variable characters for $35 \mathrm{~B}$. dothidea and $\mathrm{B}$. dothideacomplex isolates. These 35 isolates were clustered into two distinct clades (A and B) by phylogenetic analysis of ITS sequences. The representative isolates from groups I and II that were differentiated by MP-PCR analysis were close to eight published $B$.

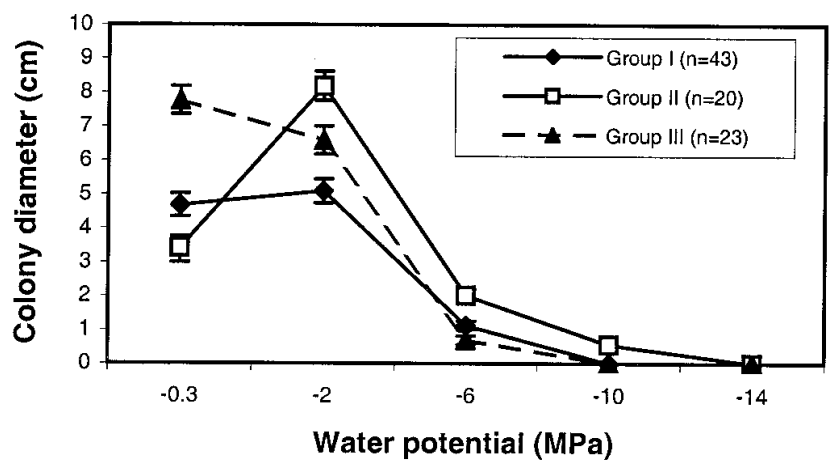

Fig. 4. Osmotic sensitivity of the three groups of Botryosphaeria dothidea isolates collected from pistachio and other host in California. dothidea isolates and six $B$. dothidea-complex isolates in $B$. dothidea (BD) clade B (Fig. 3; Table 2). The representative isolates of group III were similar to eight published $B$. dothidea isolates in BD clade A (Fig. 3). The B. dothidea and B. dothideacomplex isolates were significantly different from the outgroup isolate of B. obtusa and two isolates of B. proteae (Fig. 3).

Morphological and cultural characterization. All isolates of group III grew on APDA significantly $(P<0.001)$ faster than the isolates of group I (Table 4). Isolates of group II grew the slowest. The isolates of group III produced pycnidia on both APDA and autoclaved pistachio shoots. However, isolates of groups I and II produced pycnidia only on autoclaved pistachio shoots (Table 4).

Fungicide and osmotic sensitivity. The isolates of group III were less sensitive to sterol demethylation inhibitor tebuconazole than the isolates of groups I and II because the mean $\mathrm{EC}_{50}$ for isolates of group III was significantly higher than those of the isolates of groups I and II (Table 4). However, group III isolates showed high sensitivity to water stress (low water potential). After incubation at $28^{\circ} \mathrm{C}$ for 2 days, the radial growth of group III isolates decreased significantly $(P<0.0001)$ as water potential in media decreased from -0.3 to $-14.0 \mathrm{MPa}$. The radial growth of the group II isolates increased significantly as water potential decreased from -0.3 to $-2.0 \mathrm{MPa}$, and then declined as water potential further decreased (Fig. 4).

Pathogenicity on pistachio. For mycelial plug inoculations on pistachio shoots, each representative isolate for groups I and III caused blight on shoots 10 days after inoculation. Three isolates of group II caused blight on shoots 20 days after inoculation. All representative isolates for the three groups were capable of infecting pistachio and produced characteristic disease symptoms of Botryosphaeria blight within 2 weeks after spore suspension inoculation. There were no significant $(P>0.45)$ differences in DI among five representative isolates of group I collected from pistachio and other hosts (Table 5). The virulence of three representative isolates of group II was significantly $(P<0.05)$ lower than that of five representative isolates of group I. There was no significant difference in DI between groups I and III (Fig. 5).

\section{DISCUSSION}

In the present study, a large number of MP-PCR markers showed that most pycnidiospore-derived isolates of $B$. dothidea from other hosts were identical to those of the isolates obtained from pistachio (Fig. 2). The representative isolates CE347 from incense cedar and WA372 from walnut showed the same ITS sequences as isolate PI497 from pistachio (Fig. 3). These results strongly suggest that the isolates from pistachio and other hosts are genetically related. In a previous study, we observed that all pycnidiospore-derived isolates of $B$. dothidea obtained from other hosts were capable of infecting pistachio and produced characteristic disease symptomology of Botryosphaeria blight (9). In this study, we further found that the isolates from pistachio and those from other hosts showed similar virulence on pistachio (Table 5). These results strongly support a previous finding that other hosts

TABLE 5. Pathogenicity on pistachio of Botryosphaeria dothidea isolates representing group I collected from pistachio and other hosts

\begin{tabular}{llcc}
\hline & & \multicolumn{2}{c}{ Disease index (DI) } \\
\cline { 3 - 4 } Isolate & Host & Experiment 1 & Experiment 2 \\
\hline CE347 & Cedar & $1.256 \mathrm{a}^{\mathrm{z}}$ & $1.186 \mathrm{a}$ \\
PI497 & Pistachio & $0.982 \mathrm{a}$ & $0.787 \mathrm{a}$ \\
PI565 & Pistachio & $0.125 \mathrm{a}$ & $0.967 \mathrm{a}$ \\
RE282 & Redwood & $1.239 \mathrm{a}$ & $1.103 \mathrm{a}$ \\
WA372 & Walnut & $0.874 \mathrm{a}$ & $0.986 \mathrm{a}$ \\
\hline
\end{tabular}

$y$ Definition and calculations provided in text.

z Values in each column followed by the same letter are not significantly different according to LSD at $P=0.05$. 
of $B$. dothidea can serve as potential inoculum sources for causing disease on pistachio.

In group III, pycnidiospore-derived isolate PIL22 from pistachio was similar to the ascosporic isolates of $B$. dothidea from blackberry in mycelial growth rate, osmotic and fungicide sensitivity, DNA fingerprinting, and ITS sequences, which suggest that the pistachio isolate PIL22 and blackberry ascosporic isolates are genetically similar. This finding is further supported by the results of artificial inoculation. There was no significant $(P>0.1766)$ difference in virulence on pistachio among three tested ascosporic isolates from blackberry and the pycnidiospore-derived isolate PIL22 from pistachio. Additionally, all these ascosporic isolates produced pycnidia on pistachio. Thus, an infection induced by an ascospore can produce pycnidia that eventually provide inoculum for additional infection of pistachio. In this study, results of fungicide sensitivity tests indicated that group III isolates showed low sensitivity to the fungicide tebuconazole. Importantly, all these isolates retained high virulence on pistachio (Fig. 5). Thus, these isolates might be able to increase in pistachio orchards under selection pressure after tebuconazole applications. This is an important consideration because tebuconazole has shown potential for controlling Botryosphaeria blight in recent fungicide trials and is scheduled to be registered for pistachio $(15,16)$.

We observed a very low level of genetic variation among 43 pycnidiospore-derived isolates of $B$. dothidea in group I collected from pistachio and other hosts in central and southern California (Table 1; Fig. 2). This finding is consistent with previous studies involving the isolates collected from pistachio and other hosts in northern California (9). The low level of genetic diversity correlates with the fact that Botryosphaeria panicle and shoot blight is a relatively recent disease on California pistachio $(11,23)$. A number of studies have shown that pathogen populations from monoculture fields might be dominated by one or a few genotypes (or strains) (7,31). Kerman is essentially the only commercial pistachio cultivar currently growing in California and it is very susceptible to $B$. dothidea. Thus, the susceptible mono-cultivar of pistachio might have also led to the low genetic diversity of this pathogen appearing on pistachio.

The low genetic diversity among the isolates of $B$. dothidea from pistachio may allow us to develop molecular methodologies for detection of this pathogen. The molecular diagnosis of $B$. dothidea on pistachio may be important because identification of this pathogen is difficult based on morphological and cultural characteristics. Recently, a pair of group-specific, sensitive PCR primers has been developed based on ITS sequences, and used for detection of the pathogen of group I on pistachio and other hosts in California (Z. Ma and T. J. Michailides, unpublished data).

Of the 343 pycnidiospore-derived isolates of $B$. dothidea collected from a commercial pistachio orchard in Glenn County in 2000, only the isolate PIL22 showed similar molecular, morphological, and cultural characters as the blackberry ascosporic isolates. Isolates with similar characteristics were not observed in more than 500 pycnidiospore-derived isolates collected from other surveyed pistachio orchards in northern, central, and southern California in previous work. Thus, although three groups were identified for $B$. dothidea isolates collected from pistachio and other hosts, currently, only group I, consisting of pycnidiosporederived isolates, is predominant on pistachio in California. This finding may also be further supported by the pathogenicity and osmotic sensitivity tests. In California, there was a 5-year drought during 1990 to 1994 that coincided with sudden outbreaks of Botryosphaeria blight in California pistachio orchards (10). The isolates of group III showed higher osmotic sensitivity than the isolates of group I (Fig. 4) on petri dishes. Thus, it is possible that the isolates of group I might have had the advantage of resisting drought better than group III isolates under the drought conditions during 1990 to 1994 and spread on pistachio and other hosts in California. Furthermore, the pathogenicity tests showed that the virulence of group II isolates on pistachio was significantly lower than that of group I isolates (Fig. 5). Therefore, group I isolates might be more adapted in infecting pistachio than group II isolates in California.

One of the aims of this study was to further identify the pistachio blight pathogen by comparing the ITS sequences of pistachio isolates with those of recent published $B$. dothidea isolates. Recently, Smith et al. (25) reported that the pathogen causing Botryosphaeria blight of pistachio differentiated from $B$. dothidea since the pistachio isolates separated as a taxonomic clade between the group of $B$. dothidea (four isolates) and the group of $B$. ribis (four isolates). In this previous study, the four surveyed $B$. dothidea isolates were clustered in one group based on ITS sequences. However, Jacob and Rehner (8) reported that eight isolates of $B$. dothidea were present in two distinct groups based on ITS sequences. Using more than five $B$. dothidea isolates, Denman et al. (5), Ogata et al. (21), and Smith et al. (27) also reported that $B$. dothidea consisted of more than one ITS group. Thus, the previous conclusion (25) that the pathogen infecting pistachio differentiated from $B$. dothidea needs to be re-evaluated because the authors compared pistachio isolates with only four $B$. dothidea isolates, and the four $B$. dothidea isolates were clustered in only one ITS group.

In our study, based on comparisons of ITS sequences, we observed that our five representative isolates of group III were similar to three B. dothidea isolates surveyed by Smith and Stanosz (26) and five $B$. dothidea isolates examined by Jacob and Rehner (8) (Table 2; Fig. 3). Our five representative isolates of group I and three representative isolates of group II were close to six of Smith et al. (27) B. dothidea isolates and two of Jacob and Rehner's (8) B. dothidea isolates (Table 2; Fig. 3). Additionally, the representative isolates of the three groups caused characteristic symptoms of Botryosphaeria blight on pistachio. Based on the results of our study and other previous reports on this pathogen, the isolates collected from pistachio and other hosts in California could be considered $B$. dothidea.

In our study, we observed significant differences in MP-PCR fingerprinting, ITS sequence, and morphological and cultural characteristics among the isolates of $B$. dothidea collected from pistachio and other hosts in California. This finding is in agreement with several previous reports on this fungus $(5,8,21,27)$. According to ITS sequences, Jacobs and Rehner clustered eight $B$. dothidea isolates into two groups (I and III). However, these isolates were divided into as many as five different groups based on morphology and cultural characteristics (8). Ogata et al. (21) and Smith et al. (27) also clustered their surveyed $B$. dothidea isolates into two distinct ITS groups. Although these $B$. dothidea isolates may represent more than one species, currently, no conclusive evidence has been presented that these two ITS groups of

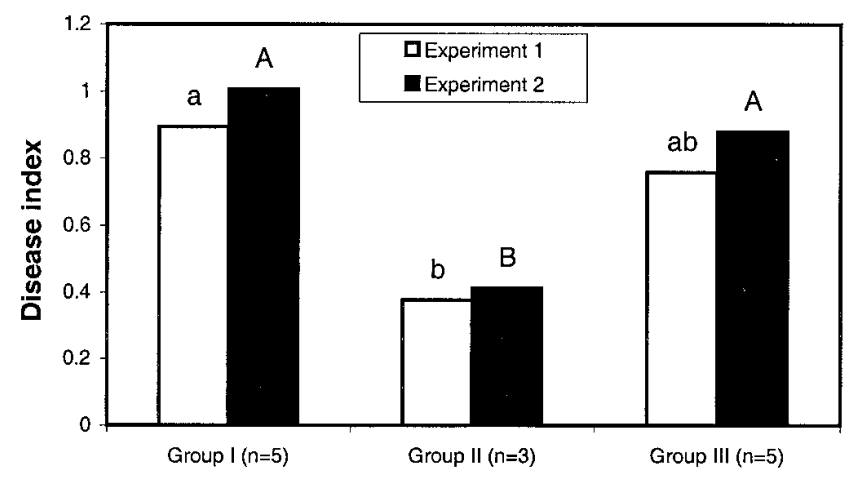

Fig. 5. Comparison in pathogenicity on pistachio among the three groups of Botryosphaeria dothidea isolates collected from pistachio and other hosts in California. Bars with the same letter for each experiment are not significantly different at $P=0.05$. 
B. dothidea are separate taxa. Thus, it seems prudent to consider the two distinct ITS groups as subspecific variation of $B$. dothidea unless more evidence supporting their separation is obtained.

\section{ACKNOWLEDGMENTS}

This research was supported in part by grants from California Pistachio Commission and the University of California BioSTAR Project awarded to T. J. Michailides. We thank B. Pryor, V. Konduri, W. J. Swart, and Y. Luo for reviewing the manuscript prior to submission.

\section{LITERATURE CITED}

1. Berbee, M. L., and Taylor, J. 1993. Dating the evolutionary radiation of the true fungi. Can. J. Bot. 71:1114-1127.

2. Britton, K. O., and Hendrix, F. F. 1982. Three species of Botryosphaeria cause peach tree gummosis in Georgia. Plant Dis. 66:1120-1121.

3. Brown, E. A., II, and Britton, K. O. 1986. Botryosphaeria disease of apple and peach in the southeastern United States. Plant Dis. 70:480-484.

4. Butin, H. 1993. Morphological adaptation and spore pleomorphism in the form-complex Dichomera-Camarosporium and Fusicoccum-Dothiorella. Sydowia 45:161-166.

5. Denman, S., Crous, P. W., Taylor, J. E., Kang, J., Pascoe, I., and Wingfield, M. J. 1999. An overview of the taxonomic history of Botryosphaeria and a re-evaluation of its anamorphs based on morphology and ITS rDNA phylogeny. Sydowia 52:129-140.

6. English, H., Davis, J. R., and Devay, J. E. 1966. Dothiorella canker, a new disease of almond trees in California. Phytopathology 56:146.

7. Garrett, K. A., and Mundt, C. C. 1999. Epidemiology in mixed host populations. Phytopathology 89:984-990.

8. Jacobs, K. A., and Rehner, S. A. 1998. Comparisons of cultural and morphological characters and ITS sequences in anamorphs of Botryosphaeria and related taxa. Mycologia 90:601-610.

9. Ma, Z., Boehm, E. W. A., Luo, Y., and Michailides, T. J. 2001. Population structure of Botryosphaeria dothidea from pistachio and other hosts in California. Phytopathology 91:665-672.

10. Ma, Z., Morgan, D. P., and Michailides, T. J. 2001. Effects of water stress on Botryosphaeria blight of pistachio caused by Botryosphaeria dothidea. Plant Dis. 85:745-749.

11. Michailides, T. J. 1991. Pathogenicity, distribution, sources of inoculum, and infection courts of Botryosphaeria dothidea on pistachio. Phytopathology 81:566-573.

12. Michailides, T. J., and Morgan, D. P. 1993. Spore release by Botryosphaeria dothidea in pistachio orchards and disease control by altering the trajectory angle of sprinklers. Phytopathology 83:145-152.

13. Michailides, T. J., Morgan, D. P., and Felts, D. 2001. Collection and characterization of Botryosphaeria dothidea from various hosts and pathogenicity studies on pistachio. Univ. Calif. KAC Plant Prot. Q. 11:3-8.

14. Michailides, T. J., Morgan, D. P., Felts, D., and Chitzanidis, A. 1998. Disease monitoring and prediction of Botryosphaeria blight in California pistachio orchards. Pages 72-79 in: California Pistachio Industry Annual Report, Crop Year 1997-1998. California Pistachio Commission, Fresno, CA.

15. Michailides, T. J., Morgan, D. P., Felts, D., Krueger, W., and Weinberger, G. 1999. Chemical control of Botryosphaeria blight of pistachio in 1998. Pages 83-84 in: California Pistachio Industry Annual Report, Crop Year
1998-1999. California Pistachio Commission, Fresno, CA.

16. Michailides, T. J., Morgan, D. P., Felts, D., Krueger, W., and Weinberger, G. 2000. Chemical control of Botryosphaeria blight of pistachio in California. Pages 123-124 in: California Pistachio Industry Annual Report, Crop Year 1999-2000. California Pistachio Commission, Fresno, CA.

17. Michailides, T. J., Morgan, D. P., Felts, D., and Ribiero, B. 1997. Disease monitoring, prediction and spread of Botryosphaeria dothidea in central California pistachio orchards. Pages 73-81 in: California Pistachio Industry Annual Report, Crop Year 1996-1997. California Pistachio Commission, Fresno, CA.

18. Nei, M. 1987. Molecular Evolutionary Genetics. Columbia University Press, New York.

19. Nei, M., and Li, W. H. 1979. Mathematical model for studying genetic variation in terms of restriction endonucleases. Proc. Natl. Acad. Sci. USA 76:5269-5273.

20. Nemec, S. 1992. Diplodia. Pages 111-114 in: Methods for Research on Soilborne Phytopathogenic Fungi. L. L. Singleton, J. D. Mihail, and C. M. Rush, eds. The American Phytopathological Society, St. Paul, MN.

21. Ogata, T., Sano, T., and Harada, Y. 2000. Botryosphaeria spp. isolated from apple and several deciduous fruit trees are divided into three groups based on the production of warts on twigs, size of conidia, and nucleotide sequences of nuclear ribosomal DNA ITS regions. Mycoscience 41:331-337.

22. Rehner, S. A., and Uecker, F. A. 1994. Sequence variation in nuclear ribosomal DNA spacers ITS1 and ITS2 in Phomopsis. Can. J. Bot. 72:237-239.

23. Rice, R. E., Uyemoto, J. K., Ogawa, J. M., and Pemberton, W. M. 1985. New findings on pistachio problems. Calif. Agric. 39:15-18.

24. Robinson, R. A., and Stokes, T. H. 1959. Electrolyte Solution, the Measurement and Interpretation of Conductance, Chemical Potential, and Diffusion in Solution of Simple Electrolytes. 2nd ed. Butterworths, London.

25. Smith, D. R., Michailides, T. J., and Stanosz, G. R. 2001. Differentiation of a Fusicoccum species causing panicle and shoot blight on California pistachio trees from Botryosphaeria dothidea. Plant Dis. 85:1235-1240.

26. Smith, D. R., and Stanosz, G. R. 2001. Molecular and morphological differentiation of Botryosphaeria dothidea (anamorph Fusicoccum aesculi) from some other fungi with Fusicoccum anamorphs. Mycologia 93:505-515.

27. Smith, H., Crous, P. W., Wingfield, M. J., Coutinho, T. A., and Wingfield, B. D. 2001. Botryosphaeria eucalyptorum sp. nov., a new species in the B. dothidea-complex on Eucalyptus in South Africa. Mycologia 93:277-285.

28. White, T. J., Bruns, T., Lee, S., and Taylor, J. 1990. Amplification and direct sequencing of fungal ribosomal RNA genes for phylogenetics. Pages 315-322 in: PCR Protocols: A Guide to Methods and Applications. Academic Press, San Diego.

29. Witthuhn, R. C., Wingfield, B. D., Wingfield, M. J., Wolfaardt, M., and Harrington, T. C. 1998. Monophyly of the conifer species in the Ceratocystis coerulescens complex based on DNA sequence data. Mycologia 90:96-101.

30. Worral, J. J., Correll, J. C., and McCain, A. H. 1986. Pathogenicity and teleomorph-anamorph connection of Botryosphaeria dothidea on Sequoiadendron giganteum and Sequoia sempervirens. Plant Dis. 70:757-759.

31. Zhu, Y., Chen, H., Fan, J., Wang, Y., Li, Y., Chen, J., Fan, J., Yang, S., Hu, L., Leung, H., Mew, T. W., Teng, P. S., Wang, Z., and Mundt, C. C. 2000. Genetic diversity and disease control in rice. Nature 406:718-722. 